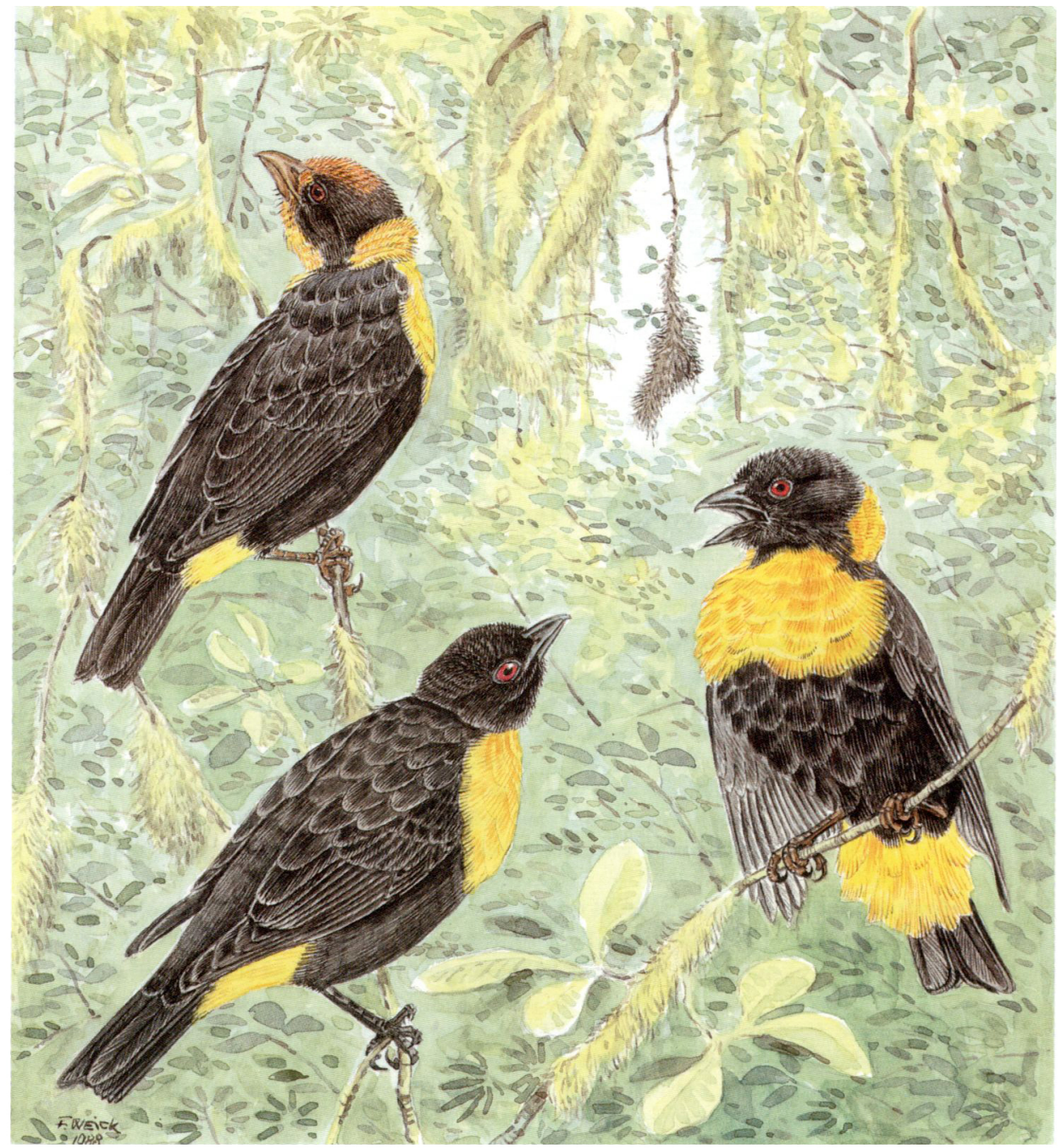




\title{
The biology of the Gola Malimbe Malimbus ballmanni Wolters 1974
}

\author{
WULF GATTER and RODERICK GARDNER
}

\begin{abstract}
Summary
The Gola Malimbe Malimbus ballmanni survives in two general areas of Upper Guinea Forest, both focused in Liberia adjacent to easternmost Sierra Leone and westernmost Ivory Coast, where the species was first recorded in the 1970 . The eastern population extends over an area of at least $18,000 \mathrm{~km}^{2}$ and may consist of some 20,000 to 50,000 birds, the species being locally common in lowland rainforest. The western population covers at least $200-300 \mathrm{~km}^{2}$, but numbers are hard to judge. Both populations are under severe threat from habitat destruction, particularly the western. $M$. ballmanni and $M$. racheliae form a superspecies as the forest-interior counterparts of the canopy-haunting M. scutatus and M. cassini. M. ballmanni is found between $8 \mathrm{~m}$ and $22 \mathrm{~m}$ in high forest (79\% of recorded cases), higher than $M$. nitens, lower than M. scutatus; it joins mixed bird parties and feeds on insects of the same size-class as in scutatus, smaller than in nitens. Annual life-cycle is seasonally adapted, with nesting when the rains end and in the transitional and dry season, occasionally in the intermediate dry season. Most birds moult in the first half of the year. Nests hang on lianas, in open galleries at 8 to $21 \mathrm{~m}$. Up to five birds may help build a nest, with labour divided between males and females (which also have different song phrases). Biometric data of adult and immature birds are given.
\end{abstract}

\section{Introduction}

In 1971 G. D. Field discovered a malimbe Malimbus in the Gola Forest of eastern Sierra Leone that did not fit any published descriptions of known species. He subsequently observed the bird on a number of occasions; all records came from a narrowly restricted region of primary rainforest, which was suffering from disturbance by logging activities. Field later decided to describe the species on the basis of his observations, naming it Malimbus golensis after the locality of discovery (Field 1979). However, Prigogine (1981) quickly pointed out that this was the same bird Wolters (1974), in a very short note, had already called Malimbus ballmanni on the basis of a single alcohol preparation from an area over $500 \mathrm{~km}$ south-east of Gola, in Ivory Coast. Nevertheless, while the scientific name Malimbus golensis was lost through precedent, the species has con-

Figure 1. A family of Malimbus ballmanni. Lower left, adult female; right, adult male singing in display position; upper left, young male; centre background, nest. Colour painting by $F$. Weick from field sketches by W.G. 
tinued to be known in English as the Gola Malimbe (e.g. Collar and Stuart 1985 , Gatter 1988a).

Today, as a consequence of fieldwork reported in full for the first time here (brief details having emerged in Collar and Stuart 1985, 1988, Gatter 1985, 1988a, Allport 1991), these two areas from which the species was first known now represent the longitudinal extremes in the known range of $M$. ballmanni. Apart from our new distributional data on the species, which has the Red Data Book status "Indeterminate" in Collar and Stuart (1985), we here provide new information on its biology (annual life-cycle including breeding biology and behaviour), plumage, biometrics, systematic position and conservation status.

\section{Materials and methods}

In the years 1981-1984 one of us (W.G.) worked as a forestry adviser and project manager in a natural forest research project in eastern Liberia. In this project various types of rainforest and their fauna were studied intensively between $5^{\circ} 30^{\prime}$ and $6^{\circ} 30^{\prime} \mathrm{N}$, representing 1,000 days' work in the forests. In addition, five expeditions of one to three months were made to mainly western parts of the country (up to 1989) and three to Ivory Coast (1990-1992).

This work has resulted in a considerable improvement in the knowledge of the avifauna of the Liberian interior which, with the exception of Mount Nimba (see Colston and Curry-Lindahl 1986), had been virtually unknown. The first results included the description of a new species, the Spot-winged Greenbul Phyllastrephus leucolepis (Gatter 1985), a provisional checklist of the avifauna of the country (Gatter 1988a), some studies of Palearctic bird migration (Gatter 1987a,b, Gatter and Mattes 1987), and a study of the annual life-cycle and biometrics of Yellow-whiskered Greenbul Andropadus latirostris (Mattes and Gatter 1989).

All records of Malimbus ballmanni were collected by chance during general expeditions concerning forestry and ornithology. More intensive studies were undertaken near Zwedru within a logged 12 ha research area covered by a grid of trails at $100 \mathrm{~m}$ intervals (Gatter 1985). Two other research areas covered $6 \mathrm{~km}^{2}$ in logged and $8 \mathrm{~km}^{2}$ in unlogged lowland forests, both of which had a grid net of $1 \mathrm{~km}^{2}$ only, but with two 1 ha plots in each $\mathrm{km}^{2}$ dedicated to botanical studies; W.G. used these plots, the associated trails and the boundaries of the research areas during forestry work, making casual observations of the malimbes whenever possible. Many other expeditions were made in various parts of different forests, mainly starting from logging roads and rivers (methods in Gatter 1988b). All mappings of whole areas were done mainly by W.G. between ophoo and 18hoo. Some of the observations were made together with F. Alkemeier, $M$. Behrndt, V. Dorka, D. and P. Gatter, M. E. J. Gore and H. Mattes. 


\section{Results}

\section{Distribution}

The first records of $M$. ballmanni were Field's (1979) from the Gola Forest in Sierra Leone on the borders with Liberia (c. $7^{\circ} 30^{\prime} \mathrm{N} 11^{\circ} 15^{\prime} \mathrm{W}$; see Figures 4,5 ). The type-locality, however, is at $5^{\circ} 50^{\prime} \mathrm{N} 7^{\circ} 28^{\prime} \mathrm{W}$ near Tai in Ivory Coast (Wolters 1974). In 1981, W.G. discovered a large population of the species between these two localities, "in the northern part of Grand Gedeh County" in south-eastern Liberia (Collar and Stuart 1985). Subsequent fieldwork showed that this third area was part of a distribution block that embraced the second, extending for at least $110 \mathrm{~km}$ along the Cavalla River into Ivory Coast (Figure 5).

In Ivory Coast records extend along the Cavalla from where the river turns north near Bakoubli (south of Toulepleu) in the north-west (c. $6^{\circ} 30^{\prime} \mathrm{N} 8^{\circ} 25^{\prime} \mathrm{W}$ ) eastwards as far as $6^{\circ} 22^{\prime} \mathrm{N} 8^{\circ} \mathrm{oo}$ 'W in "forêt classée de la Goin" and approximately $6^{\circ} 10^{\prime} \mathrm{N} 7^{\circ} 40^{\prime} \mathrm{W}$ in "forêt classée du Cavally", with 18 records from the Ivoirean side of the river apart from those made directly along the river. In 1992 W.G. found the bird in the zone north-west of Taï National Park and the Réserve de Faune du N'Zo, all these records being estimated to be exactly east of the town of Zagne but outside of protected area limits. Although searches for the species in Taï National Park have drawn a blank (Gartshore 1989) or at least resulted in possible sightings only (see Allport 1991), our records convince us that it is present in the northern sector.

In adjacent eastern Liberia, records from the Glio region just beyond the northern boundary of the Grebo National Forest lie exactly west of the typelocality across the Cavalla River. South of it in the well-studied Grebo National Forest near Glaro the species has not been found, mirroring the situation in

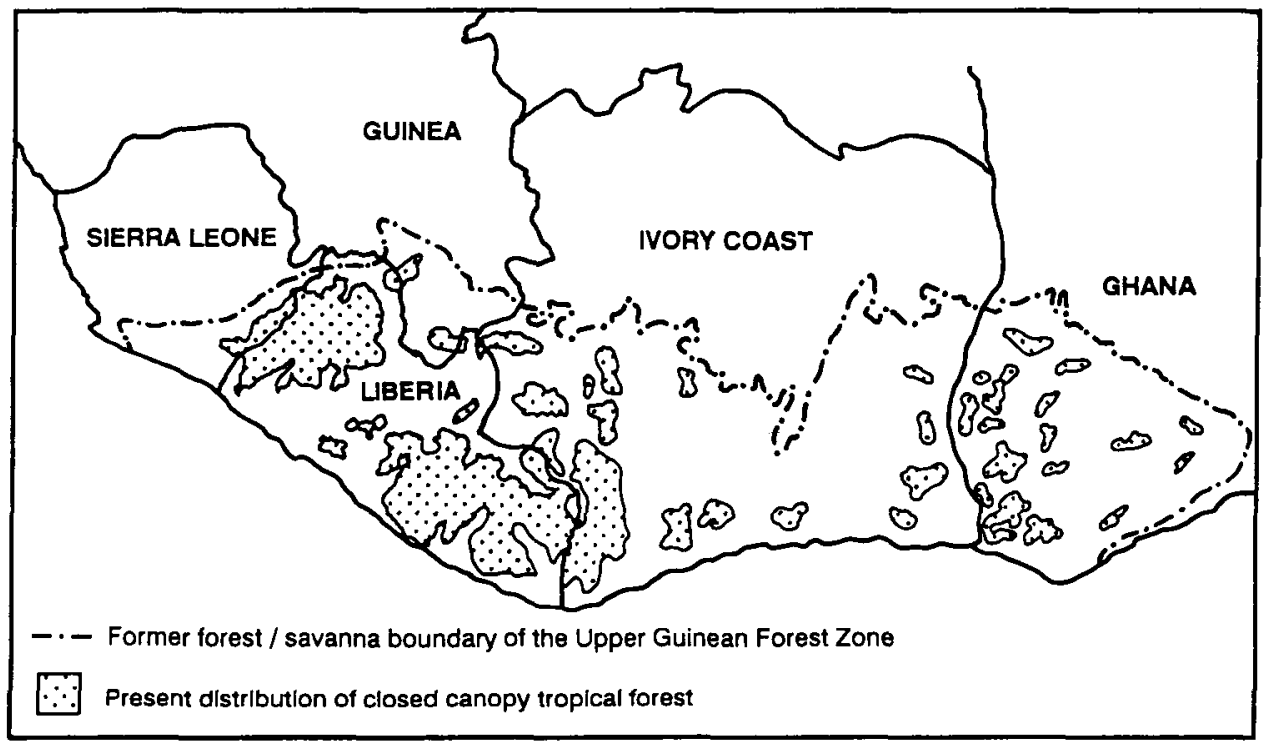

Figure 2. Present distribution of closed tropical canopy forest in the Upper Guinea Zone. (Based on Liberian FDA annual report 1989.) 


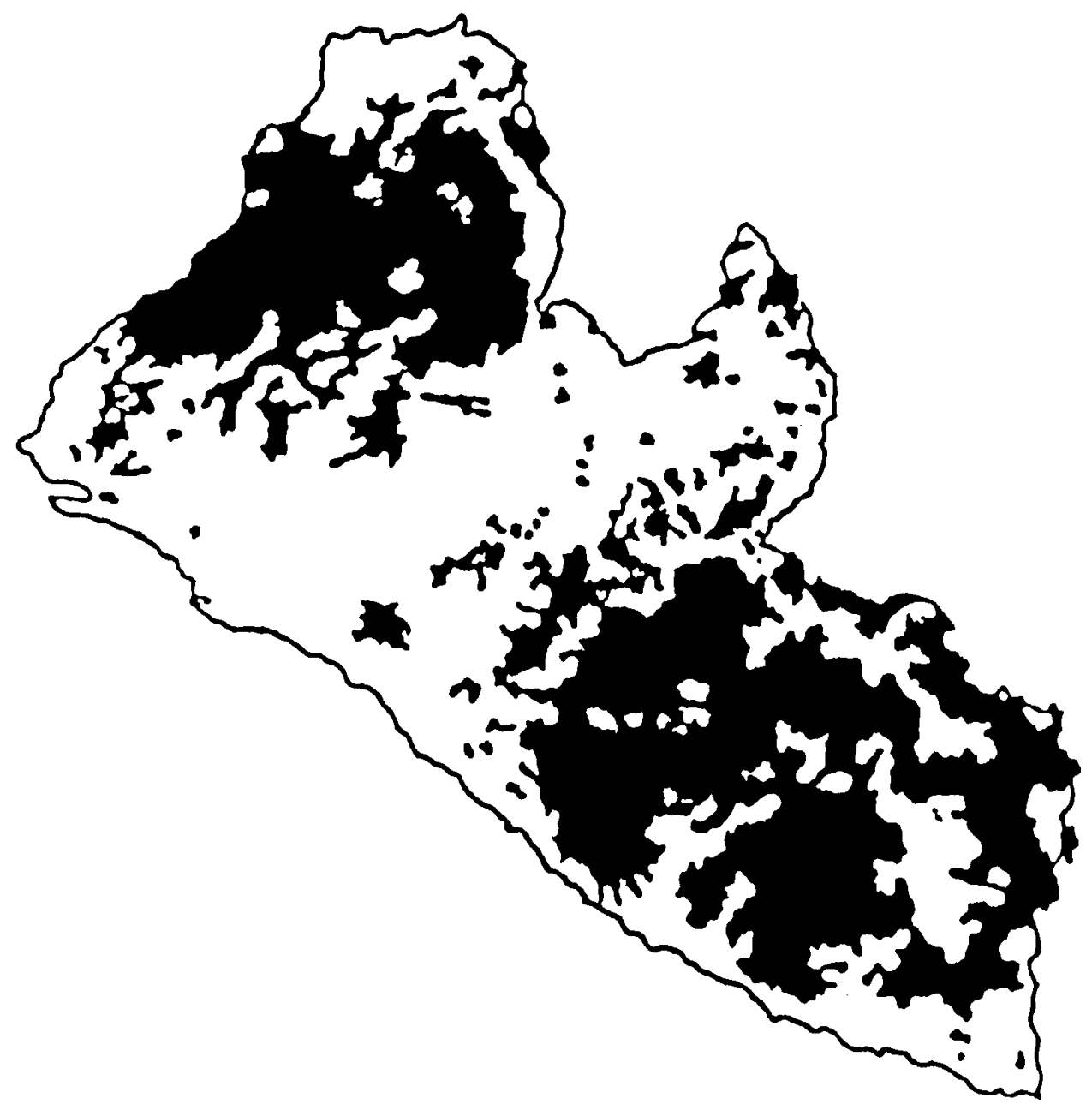

Figure 3. Distribution of closed tropical canopy forest (shaded areas) in Liberia (after Gatter 1984).

south-central Taï National Park at the same latitude. The south-western limits lie in and west of Sapo National Park (north-east of Greenville), where during a two-month survey in 1987 W.G. discovered a population as far south as $5^{\circ} 20^{\prime} \mathrm{N}$ $8^{\circ} 50^{\prime} \mathrm{W}$ : based on 24 observations during this period, $M$. ballmanni is known to occur at least throughout the park's western border area, along the Sinoe River, near the recently built Ggbaboni Creek Camp within the park, and from there southwards to Juazohn (Figure 5).

In Liberia's Gola Forest in 1989 W.G. found further populations adjacent to Sierra Leone's Gola Forest (nest found at c. $7^{\circ} 25^{\prime} \mathrm{N} 11^{\circ} 5 \mathrm{O}^{\prime} \mathrm{W}$, several sight records of different groups at $\mathrm{c} .7^{\circ} 22^{\prime} \mathrm{N} 11^{\circ} 38^{\prime} \mathrm{W}$ ) (Figure 5). However, in the same year the original locality in which the species was found in Sierra Leone's Gola Forest was thoroughly searched without success (Allport et al. 1989, Allport 1991).

Thus although the known area of distribution extends from western Ivory Coast through Liberia to easternmost Sierra Leone, records are restricted to the 


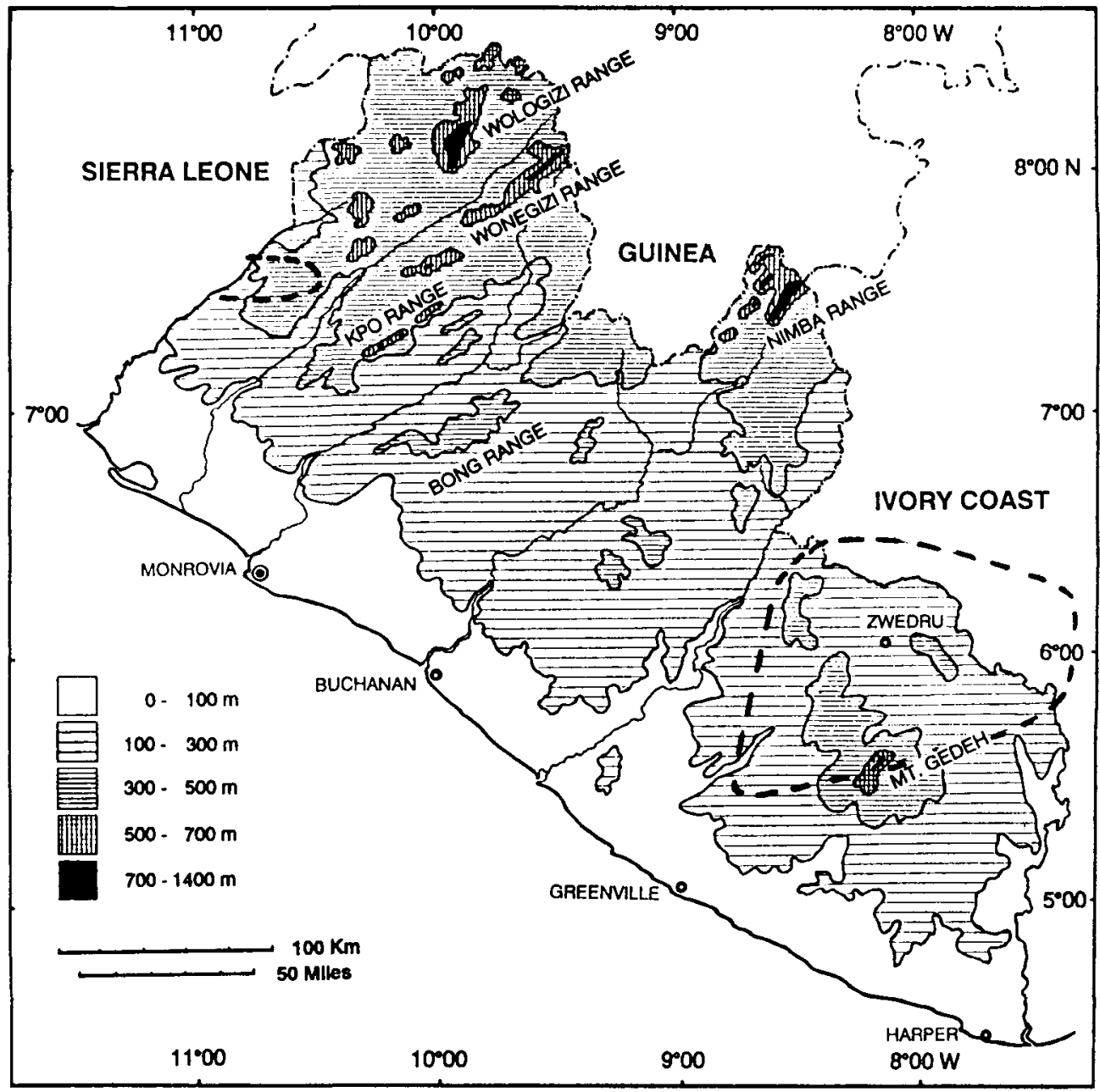

Figure 4 . Borders (represented by thick dashed lines) of known range of Malimbus ballmanni in Liberia and the Ivory Coast.

two largest remaining forest islands of the Upper Guinea Forest, namely ( 1 ) the eastern block, ranging from central Liberia in the west to the Taï National Park in the east, and (2) the western block, focused on southern Lofa County, Liberia, by the border with Sierra Leone (Figures 2,3). These two areas are now well separated from each other, the closest points at which the species has been recorded in each being nearly $300 \mathrm{~km}$ apart. It appears that the species does not reach either the southern or the northern boundaries of the rainforest. The eastern population occupies about $18,000 \mathrm{~km}^{2}$; the western population at least several hundred square kilometres. All known localities are in primary forest, slightly logged high forest, or very old secondary forest. Some $40 \%$ of the eastern habitat is at present covered by primary and very old secondary forest.

The climatic conditions are not identical in both regions; in particular, the rainfall varies. In Gola Forest of Sierra Leone and in adjacent Liberia, a Sudan type régime with one rainy season and approximately 3,000 $\mathrm{mm}$ of rainfall oper- 


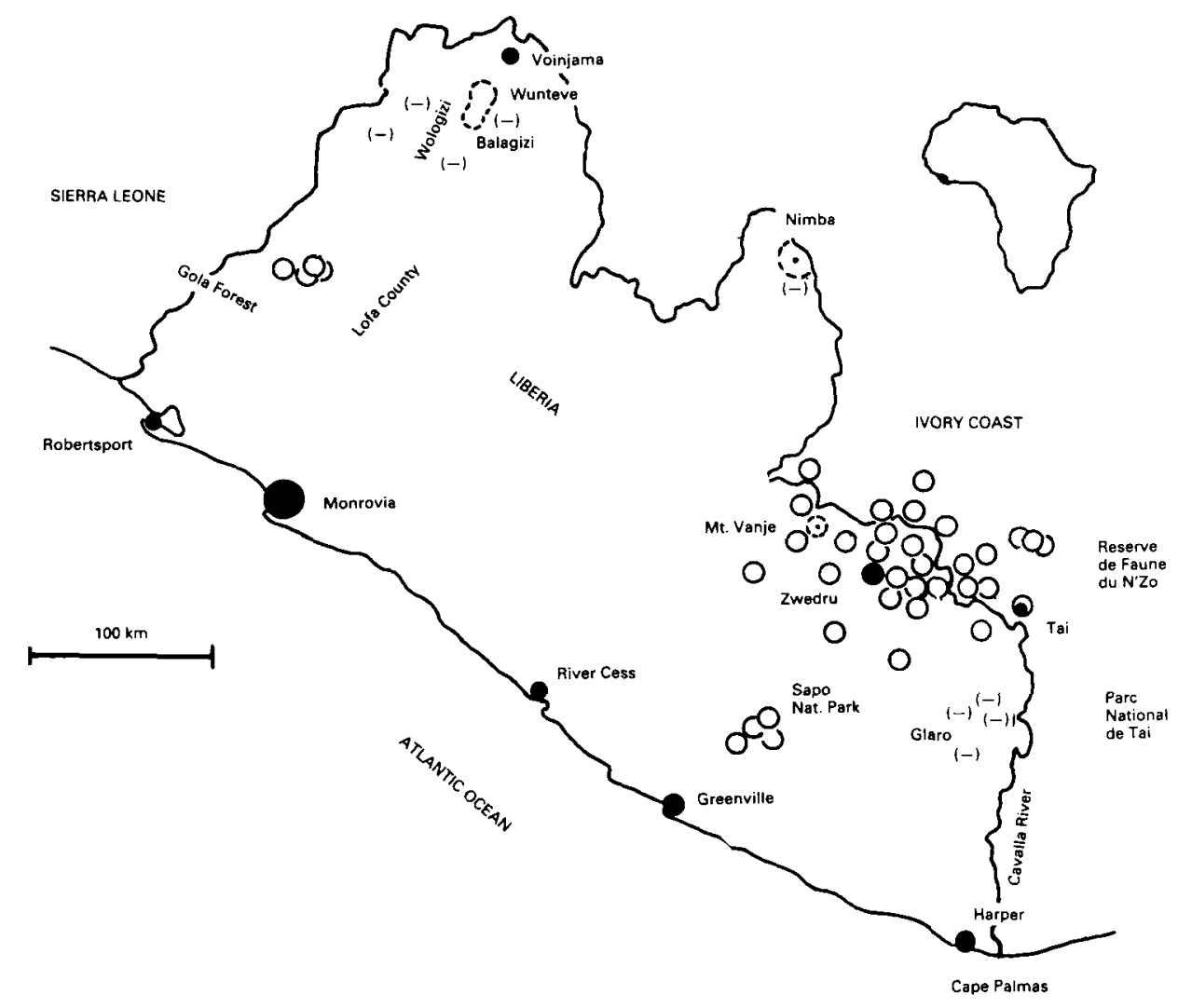

Figure 5. Map of Liberia. Filled circles, towns; open circles, records of Malimbus ballmanni; dash in brackets, area well studied, but no $M$. ballmanni found.

ates, whereas in eastern Liberia a semi-equatorial type of rainfall predominates with two rainy seasons, one marked dry season, and a short intermediate dry season in July and August, yielding altogether about 2,000 $\mathrm{mm}$ (Zwedru, Figure 7) to $3,500 \mathrm{~mm}$ (Sapo National Park) of rain per year (Schulze 1973).

\section{Vertical distribution and density}

The vertical distribution of $M$. ballmanni was determined mainly during random transects. The heights were estimated by W.G., who has undertaken thousands of height measurements of trees in Liberia. In all, 239 observations were analysed (Figure 6).

Most observations (38\%) were made between 8 and $12 \mathrm{~m}$ height (canopy of lower storey), with $23 \%$ between 13 and $17 \mathrm{~m}$ and $18 \%$ between 18 and $22 \mathrm{~m}$ (hence $79 \%$ between 8 and $22 \mathrm{~m}$ ). The species was found below $5 \mathrm{~m}$ or above $25 \mathrm{~m}$ on seven occasions each only (including being caught five times in mistnets at c. $2 \mathrm{~m}$, these records being excluded from the analysis).

From these observations $M$. ballmanni inhabits on average a higher stratum than Gray's Malimbe $M$. nitens, but a lower one than Red-headed Malimbe $M$. rubricollis and Red-vented Malimbe M. scutatus. From data given in Brosset and 


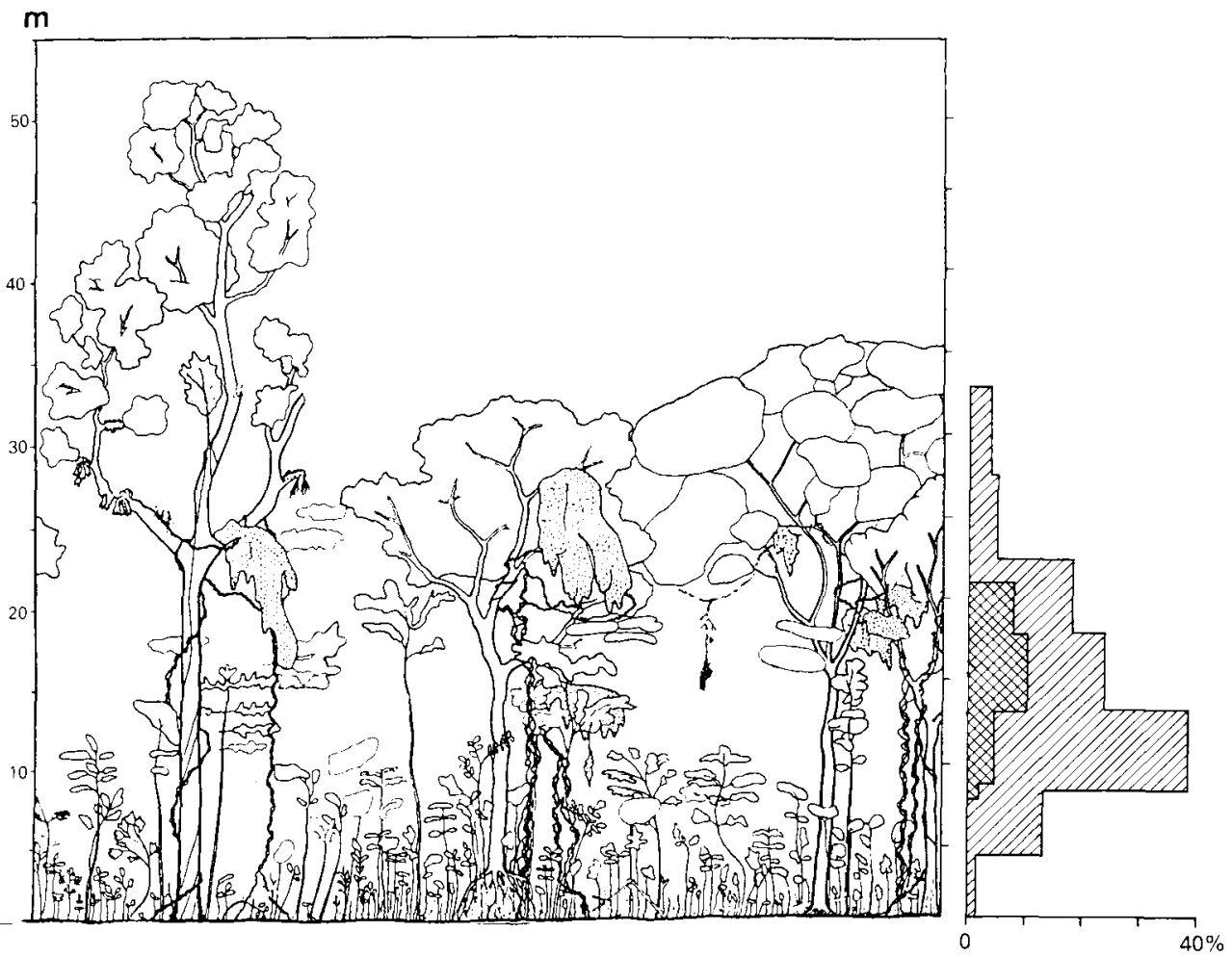

Figure 6. Vertical distribution of Malimbus ballmanni in 239 cases of foraging (hatched), expressed as percentages, and based on 13 nests (cross-hatched), expressed in numbers of nests. In the drawing a typical nesting site is on the right.

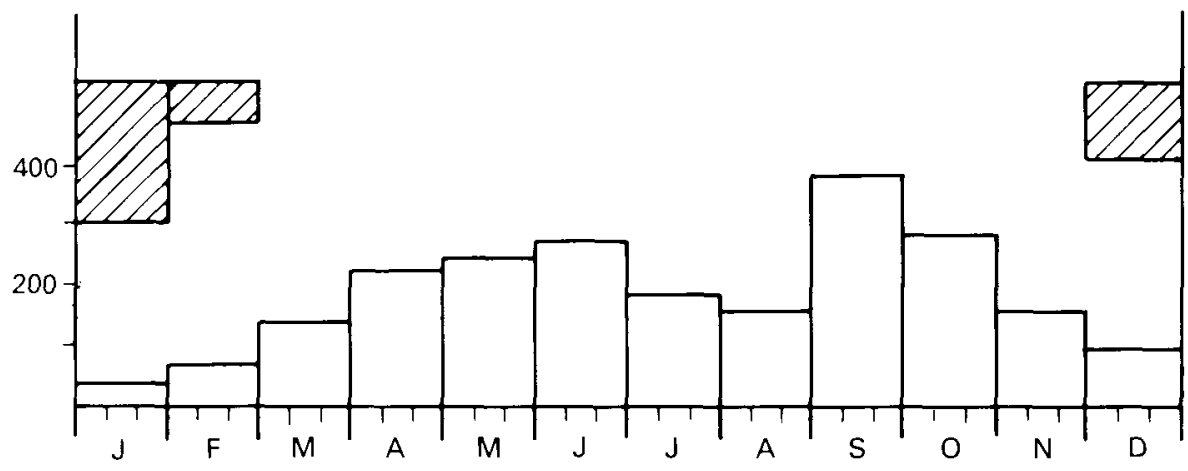

Figure 7. Distribution of annual precipitation (mm) at Zwedru, south-eastern Liberia, and occurrence of the harmattan wind (hatched).

Erard (1986), Rachel's Malimbe $M$. racheliae appears to occupy higher strata than $M$. ballmanni, being observed only above $10 \mathrm{~m}$.

In a survey area of only 12 ha near Zwedru, up to three nests of $M$. ballmanni could be found occupied at any one time. Along a line of $4.2 \mathrm{~km}$ in primary 
forest that was checked at frequent but irregular intervals, up to two occupied nests were found simultaneously. Both in the northern Grand Gedeh County and in Sapo National Park, flocks were found several times daily at separate points close to the path along a $1 \mathrm{~km}$ stretch. Locally, at least, the population density of $M$. ballmanni is thus very much higher than that of $M$. racheliae in Makakou, Gabon, which occurs at an estimated one pair per $1.5 \mathrm{~km}^{2}$ (Brosset and Erard 1986); ballmanni might reasonably be described as locally common in lowland rainforest.

\section{Annual life-cycle}

The main period of nest-building occurred at the height of the second half of the rainy season from September to October (Figure 8). A few observations were made of birds building nests before the start of the intermediate dry season (Figure 7) in July and August. Newly finished nests were not found during the intermediate dry season.

Dependent young, being fed outside the nest, were observed from the end of October until the middle of March, while independent young were seen from the end of January to the middle of May (Figure 8).

An immature male moulting into adult plumage was caught in a net at the end of May. Moult of remiges and rectrices was found on 11 birds taken between December and the beginning of August in all months except April (Figure 8). In the main breeding season between September and December only one of five birds was moulting. In the period from January to July four birds were moulting, whereas nine were not.

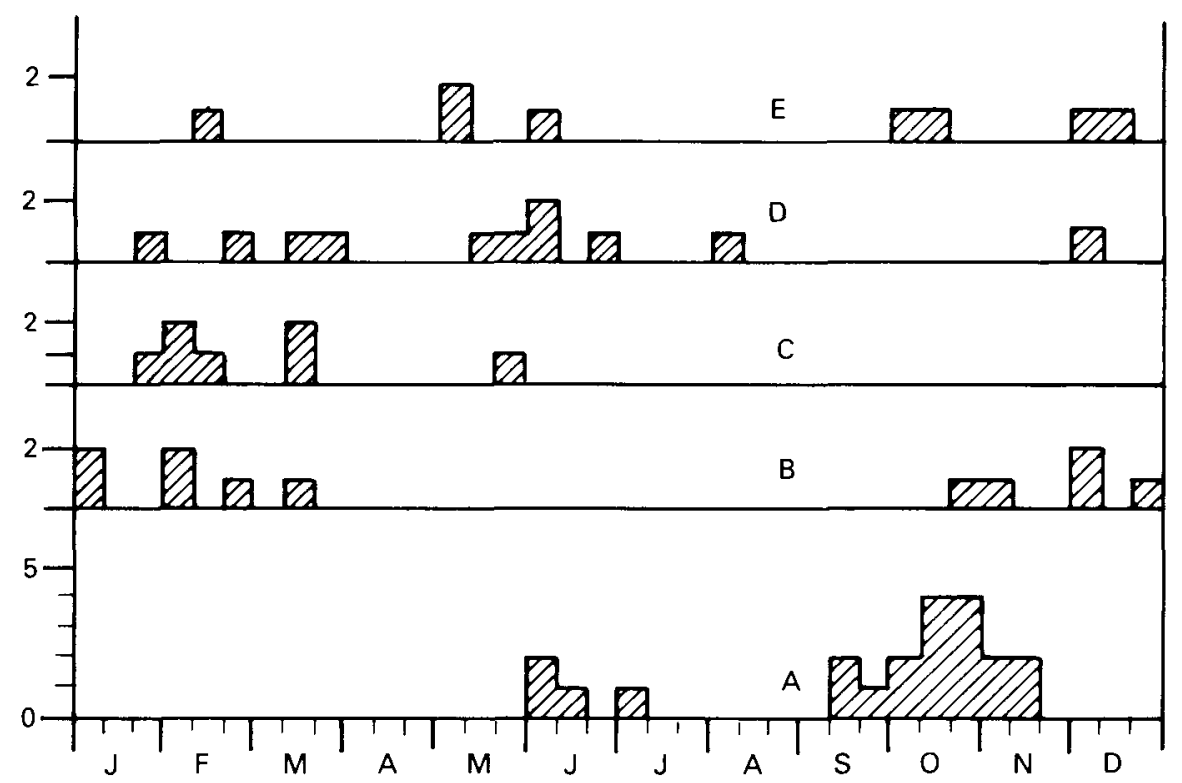

Figure 8. Annual cycle of Malimbus ballmanni based on number of records of (A) nestbuilding, (B) dependent young, (C) independent young, (D) moulting birds, and (E) non-moulting birds. 


\section{Nest and nesting height}

Thirteen nests of $M$. ballmanni were found by W.G. The nest is a free-hanging "inverted sock", as in other species of the genus Malimbus. The tubular spout entrance does not (or at least not always) become narrower towards the nest cavity, which is the case with the nest of $M$. scutatus. The whole construction is an (estimated) 60 to $110 \mathrm{~cm}$ in length. The pendant anchoring structure alone is $25-70 \mathrm{~cm}$ long. The nest itself is about $35-45 \mathrm{~cm}$ long, more than half of it consisting of the spout (Figure 9). All nests found were suspended from the ends of vertically hanging vines (never on climbing palms Ancistrophyllum, etc.), and thus accord with the findings of Brosset and Erard (1986) concerning $M$. racheliae: "à la pointe de lianes".

Apparently important in the choice of nest-site is its distance from branches,

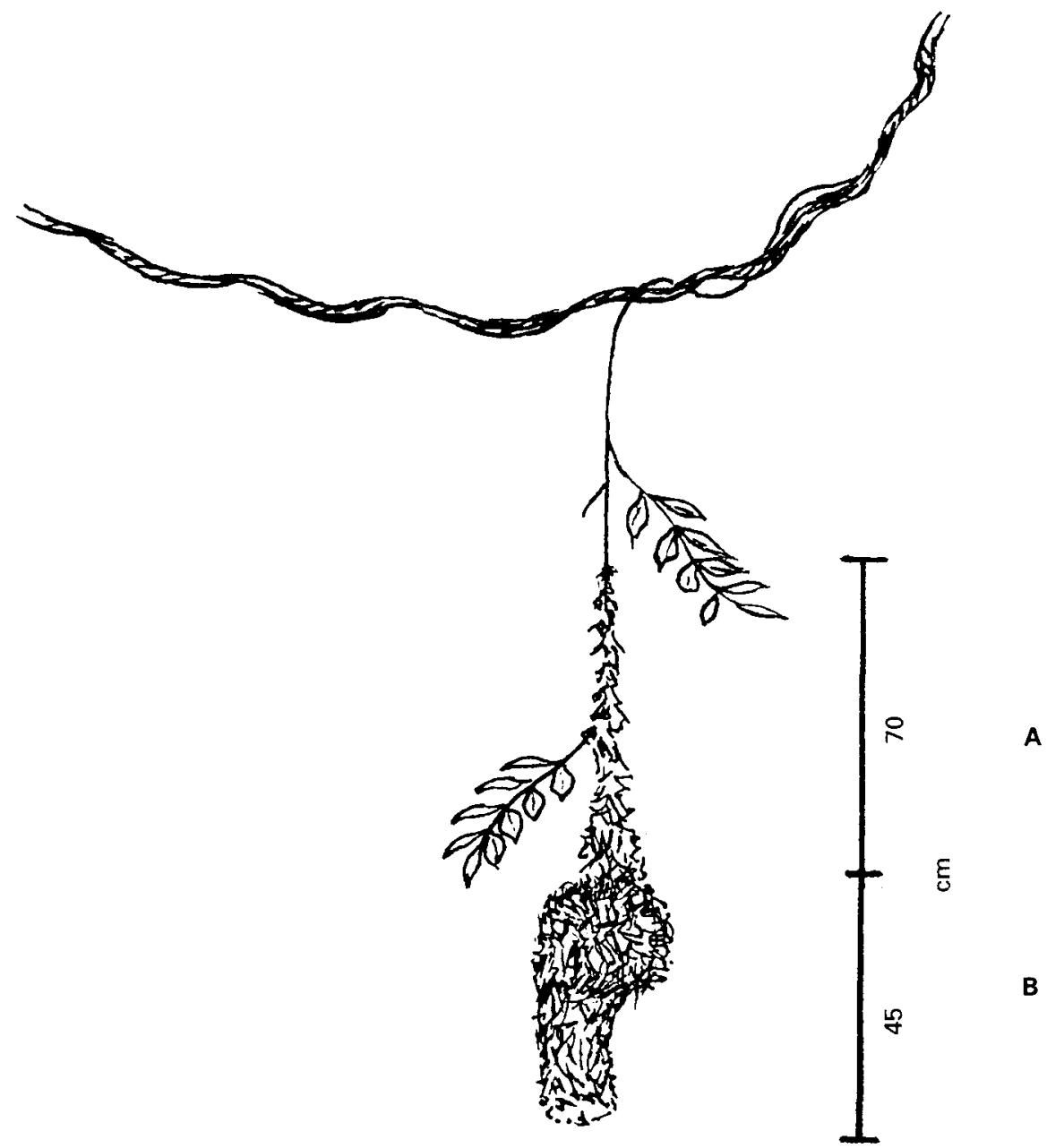

Figure 9. The nest of Malimbus ballmanni. A, pendant anchoring structure; B, nest (see text). 
which affects access by predators. The lateral distance to branches and treetrunks in some instances was about $4-6 \mathrm{~m}$, in others only $1.5-2.5 \mathrm{~m}$. Those nests hanging in free "halls" were less often destroyed (i.e. visibly interfered with) by predators than those at short distances from neighbouring branches. In only one case did the nest have contact with the ground in the form of a thin, hanging liana. The lowest nest hung at a height of $8 \mathrm{~m}$, six were at a height of $10-15 \mathrm{~m}$, five at 16-20 $\mathrm{m}$, and the highest was $21 \mathrm{~m}$ (Figure 6).

\section{Behaviour}

In display and threat behaviour, the yellow feathers play a dominant role (Figure 1 ). The breast and nape feathers are raised to make the head and body appear more powerful. The wings are slightly opened and held at an angle to the body. Occasionally the tail is held slightly raised during display, showing a flash of yellow feathers at the sides of the tail when viewed dorsally.

Song phrases or corresponding sequences of calls can be heard throughout the year, and are the best indication of the presence of the species in a mixed flock. Phrases have been heard from males that can be transcribed as "cheg chig cheg cheg chega zzzzzzzzzzzzzzzzz", being a rough, discordant series of chattering sounds followed by a wheezing phrase lasting about three seconds, which is strikingly similar to the call of the Village Weaver Ploceus cucullatus. Song was often also heard from females: it resembles the first phrase of the male song and can be described as "cheg cheg chig chag chaag cheg chiiig". These songs (from both males and females) can be heard at a distance of $100 \mathrm{~m}$, but they are quieter than the calls of $M$. scutatus. No recordings were made.

$M$. ballmanni joins mixed bird parties all year round. Nest-building takes place when the bird party passes through the nesting area at irregular intervals several times a day. Within such a mixed bird party the social unit of the M. ballmanni group can consist of two to eight birds.

Between two and five individuals can engage simultaneously in building one nest. It is uncertain whether all of these birds have started or are going to start their own nests at the same time. More than ten visits to the nest were witnessed in five minutes. Up to three birds may be present on a nest-in-progress at any one time, whilst others fly from it to collect material or wait nearby for a place to become vacant so that they can build.

When the bird party moves on, the nest-building can cease for several hours. However, it resumes immediately the flock reaches the nesting area of the next pair or social unit. If young are in the nest, three or more birds can be seen feeding them, but again only when the mixed feeding flock passes through the area. The sequence of events between the various nest visits was not determined because the flocks disappear from view for periods up to several hours, moving from the plot areas with their footpaths into adjacent impenetrable forest.

The division of labour between the sexes at the different parts of the nest is shown in Table 1. This shows that the anchoring of the nest on the liana and other outside work is the chief task of the males. The entrance spout and the interior are primarily done by the females.

In 159 observations of $M$. ballmanni individual adult birds accounted for $27 \%$, pairs for $46 \%$, and trios for $28 \%$ only (Figure 10). In 24 small groups with young 
Table 1. Number of flights to nest of males and females and the distribution of building activity at different parts of the nest

\begin{tabular}{lccccc}
\hline & Outside & Inside & $\begin{array}{c}\text { Anchoring } \\
\text { structure }\end{array}$ & $\begin{array}{c}\text { Entrance } \\
\text { spout }\end{array}$ & Total \\
\hline Male & 35 & 13 & 15 & 4 & 67 \\
Female & 8 & 32 & 2 & 12 & 54 \\
Total & 43 & 45 & 17 & 16 & 121 \\
\hline
\end{tabular}

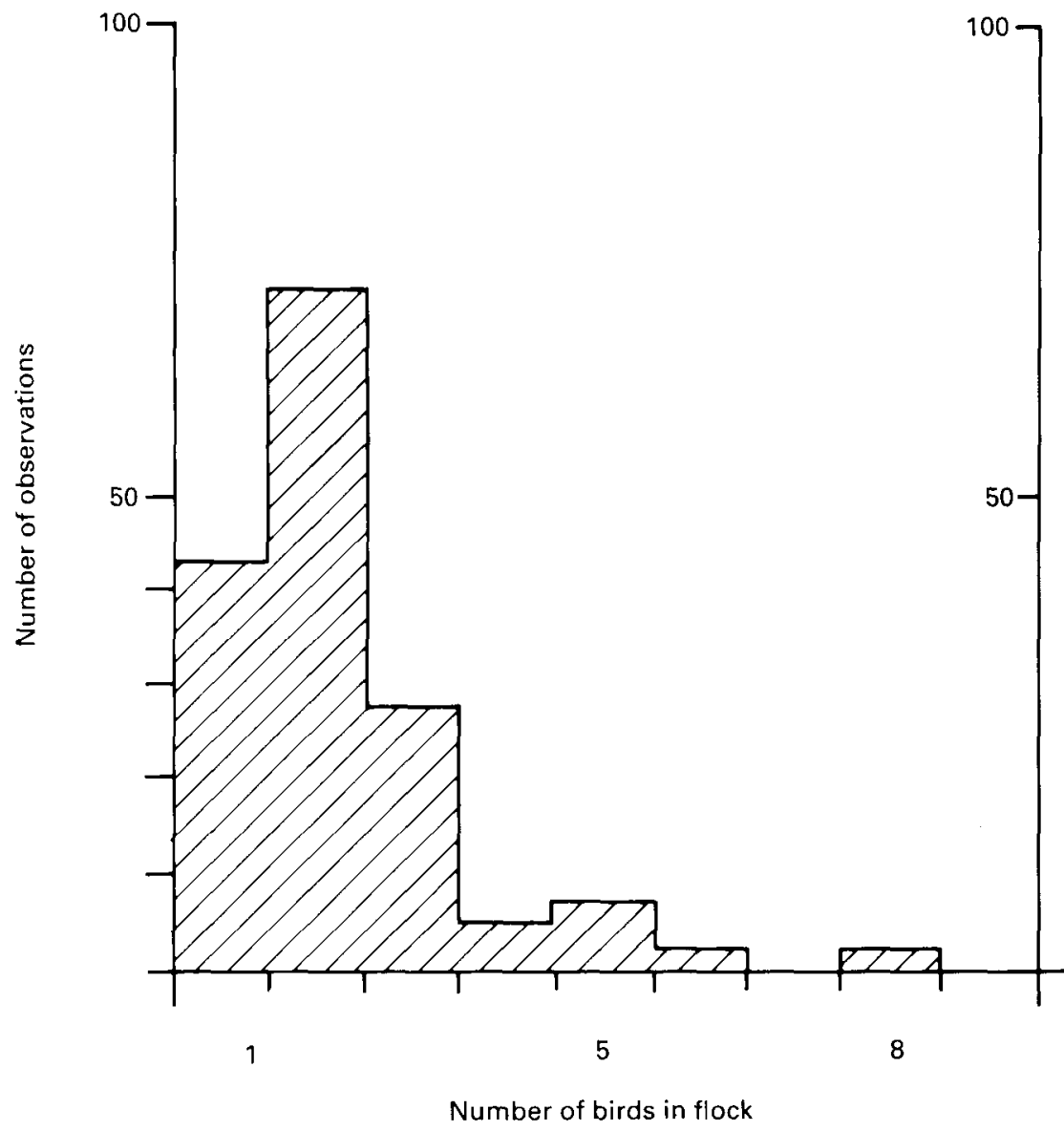

Figure 10. Frequency diagram of flock-size distribution of Malimbus ballmanni from 159 recorded observations near Tchien, Zwedru, south-eastern Liberia, and in Ivory Coast.

birds, there were 11 individual birds with $1-2$ young and 12 pairs with $1-2$ young. In one trio with one young bird the male/female constitution could not be ascertained. 
Food

Malimbus ballmanni is a completely insectivorous species. It forages by investigating leaves and thin twigs actively like a tit Parus, gleaning arthropod prey; it does not search holes in bark or dead leaf-clusters, and shows little interest in the dense cover of tangled vines. Larger prey consists mainly of grasshoppers and mantids. In roughly 15-20 observations per species, the prey length preferred by $M$. ballmanni was chiefly in the range $1-30 \mathrm{~mm}$, thus on average much less than that of $M$. nitens $(5-70 \mathrm{~mm})$ and closer to the size of prey that has been ascertained for $M$. scutatus, with which it does not come into contact because of the difference in their vertical distribution.

\section{Plumage and biometric data}

The plumage of the adult male (Figure 1, right) is shiny and deep black, with a bright cadmium- to orange-yellow breast, bright cadmium-yellow undertailcoverts (rarely with a hint of orange-yellow), and an orange-yellow to cinnamon nape. The yellow nape almost reaches the yellow breast feathers laterally, but it is usually separated from them by a few black feathers. There is a clear indentation formed by a few small black feathers at the bottom of the breast spot (Figure 1). The underside of the tail and wing is matt grey, the underwingcoverts are greyish black, worn feathers appearing greyer, especially on the mantle and back.

The plumage of the adult female looks similar to that of the male, but it lacks the yellow nape (Figure 1, lower left).

Immature males can be identified by their pale to orange-yellow or even matt orange-brown forehead, crown and throat, which are black in adults. The yellow of the chin and throat runs into the yellow of the breast feathers. The nape bar is yellow, but less extensive and paler than in adults and often restricted to the centre of the nape. The breast feathers are cadmium- to orangeyellow, and the black indentation at the bottom of the breast spot is less clear than in adult birds. The undertail-coverts are cadmium-yellow. The undersides of the wings are lighter grey as the whole plumage appears greyer and less shiny than in adults.

Juvenile females correspond in plumage to the juvenile males, but lack the yellow nape bar. The illustration of an immature bird in Field (1979, Figure 1, upper right) does not depict a juvenile but the transitional plumage in a young female still with juvenile bill.

In adults the bill is deep and shiny black, in young and immature birds more horn-yellow, turning darker with increasing age to horn-brown from the upper to the lower side, so that immatures often show horn-yellow only on the underside of the mandible. The eyes are bright wine-red, paler in immatures. The feet in immatures show a deep sepia with horn-brown claws. In adult birds the tarsus and the upper side of the toes are black, whereas the underside of toes and claws remain sepia in colour.

Measurements of 21 birds collected or caught and released around Zwedru were taken and are given in Table 2. The tips of the primaries and the rectrices on some skins were very worn. 
Table 2. Biometric data on adult and juvenile males and females of Malimbus ballmanni

\begin{tabular}{|c|c|c|c|}
\hline Wing & $\begin{array}{l}\text { adult male } \\
\text { adult female } \\
\text { juvenile male } \\
\text { juvenile female }\end{array}$ & $\begin{array}{l}(10) \\
(7) \\
(3) \\
(1)\end{array}$ & $\begin{array}{l}84-89 \mathrm{~mm} \text {, fresh } 85-94 \mathrm{~mm} \\
82-90.5 \mathrm{~mm} \text {, fresh } 84-92 \mathrm{~mm} \\
80-84 \mathrm{~mm} \text {, fresh } 83-87 \mathrm{~mm} \\
79-80 \mathrm{~mm} \text { (both wings) }\end{array}$ \\
\hline Tail & $\begin{array}{l}\text { adult male } \\
\text { adult female } \\
\text { juvenile male } \\
\text { juvenile temale }\end{array}$ & $\begin{array}{l}(10) \\
(7) \\
(3) \\
?\end{array}$ & $\begin{array}{l}57-64 \mathrm{~mm} \\
60-64 \mathrm{~mm} \\
58-59 \mathrm{~mm}\end{array}$ \\
\hline $\begin{array}{l}\text { Bill from } \\
\text { skull }\end{array}$ & $\begin{array}{l}\text { adult male } \\
\text { adult female } \\
\text { juvenile male } \\
\text { juvenile female }\end{array}$ & $\begin{array}{l}(8) \\
(5) \\
(3) \\
?\end{array}$ & $\begin{array}{l}16.5-17.5 \mathrm{~mm} \\
16.0-17.5 \mathrm{~mm} \\
16.0-17.5 \mathrm{~mm}\end{array}$ \\
\hline Tarsus & $\begin{array}{l}\text { adult male } \\
\text { adult female } \\
\text { juvenile male } \\
\text { juvenile female }\end{array}$ & $\begin{array}{l}(8) \\
(5) \\
(3) \\
?\end{array}$ & $\begin{array}{l}20.0-22.5 \mathrm{~mm} \\
20.0-21.5 \mathrm{~mm} \\
20.0-22.5 \mathrm{~mm}\end{array}$ \\
\hline
\end{tabular}

The type-specimen in Bonn, Germany (Wolters 1974), and 16 specimens collected by W.G. in eastern Liberia are the only ones in scientific collections. Fifteen skins are in the Museum für Naturkunde, Stuttgart, Germany, and one was donated to the British Natural History Museum at Tring in 1984.

\section{Discussion}

The fauna of West Africa as we encounter it today has only developed in very recent geological time (White 1979, Hamilton 1982, Coe 1986). A comparison of the numbers of species of birds shared between the two lowland forest regions, the Upper and Lower Guinea Forests, strongly indicates the likelihood that they were once connected, while the strong representation of local endemics shows that they have been isolated, perhaps repeatedly, from one another in the past. The periodic isolation of the Upper Guinea Forest has led to the loss (or non-colonization) of a few bird species on the one hand, but to the evolution of several other species on the other. The present-day separation of these two forest areas by a savanna belt (Dahomey Gap) has further reduced genetic exchange between the two areas.

The populations of many species have followed different paths of development in the two parts of the Guinea Forest, as illustrated by the divergence from common ancestry of $M$. ballmanni in the Upper Guinea and $M$. racheliae in the Lower Guinea Forest (Wolters 1974, Field 1979). Our data and observations, mainly relating to behaviour and plumages, certainly strengthen the case for considering $M$. ballmanni and $M$. racheliae members of a superspecies. Field (1979) also judged that $M$. ballmanni is most closely related to $M$. racheliae. Hall and Moreau (1970), in ignorance of the existence of ballmanni, already discussed the possibility of either $M$. cassini or $M$. scutatus forming a superspecies with racheliae. Similarly, scutatus and cassini must be treated as allopatric members of another superspecies (as long as we have only field records but no specimens of cassini collected within the Upper Guinea Forest: Grimes 1987); Haffer (1992) 
treats them as a parapatric species pair. The four species are members of two very closely related species groups.

Up to now Malimbus ballmanni has been recorded only from the western part of the Upper Guinea Forest, but it may have been overlooked in the remaining forest reserves in Ivory Coast east of Taï and in Ghana, or may already have vanished there because of forest destruction (see Figures 2,3), as seems to have taken place in Sierra Leone (Allport et al. 1989).

In its annual life-cycle, $M$. ballmanni corresponds to Andropadus latirostris in Liberia (Mattes and Gatter 1989), and thereby shows a clear adaptation to the seasons of the lowland rainforest. There are also indications that $M$. ballmanni, like $A$. latirostris, has a minor breeding season in the short intermediate dry season in July/August (Figure 7), and a major breeding season in October/ November. In $A$. latirostris most of the broods are probably raised in November/December (Mattes and Gatter 1989). At the end of the rainy season pulli have a markedly increasing supply of insects available (Gatter 1986). For $M$. ballmanni it is also clear that breeding, raising of young and, to a lesser extent, moult are correlated with the end of the rainy season and the following dry season.

Compared to the nests of other members of the genus, that of $M$. ballmanni is closest in structure to those of $M$. scutatus and cassini, but it is much less elaborate and appears untidy, failing to achieve the technical perfection of their nests, with their extreme extension of the spouts. Furthermore it lacks the association with palms, a point in common with $M$. racheliae. In this regard the claim in Hall and Moreau (1970:296) that M. scutatus, cassini and racheliae "all build similar nests with long entrance tubes, placed high in palm trees" is inapplicable to racheliae. M. ballmanni and racheliae, in contrast to scutatus and cassini, have not been found to build nests in palms, suspending them instead from lianas (see above).

The (unfinished) nest of $M$. racheliae is said by Brosset and Erard (1986) to be similar to that of Red-crowned Malimbe $M$. coronatus, which does not occur in the Upper Guinean Forest. The nest of the latter species is "elongated with a short wide spout below" (Mackworth-Praed and Grant 1973) or "does not have a long spout" (Hall and Moreau 1970). The thirteen nests of M. ballmanni found by W.G. differed distinctly from these descriptions. The spout is shorter than in $M$. scutatus, but longer than in M. nitens, malimbicus (Crested Malimbe) and rubricollis.

As inhabitants of the top storeys of the forest, $M$. scutatus and probably also cassini are very mobile and good fliers, ranging over a more extensive territory. M. ballmanni and racheliae are, on the other hand, highly sedentary inhabitants of the forest interior. The loud calls of $M$. scutatus and cassini (resembling those of the Palearctic Red Crossbill Loxia curvirostra, which in many ways leads a similar life) are in keeping with this wide-ranging behaviour. In contrast, $M$. ballmanni and racheliae with their quieter calls resemble the other weavers of the forest interior more closely.

Brosset and Erard (1986) have studied the social nest-building behaviour of $M$. racheliae. Observations of ballmanni supplied considerable additional details. Brosset and Erard (1986) found that a social group of racheliae consists of a trio (two males and a female) ("dont les membres restent constamment ensemble"), 
and juvenile birds stay with that group. Social nest-building by ballmanni, scutatus and cassini is similar to that of racheliae. The manner of feeding of ballmanni along thin branches corresponds to that of scutatus (Gatter in prep.).

Within the genus Malimbus, almost all species have black and red in their plumage. $M$. racheliae is the only one to have yellow additionally in all plumages. In $M$. ballmanni there is no red in any plumage. It is therefore the only malimbe that is purely black-and-yellow.

M. ballmanni cannot be confused with any other bird (Figure 1). Although it most closely resembles the Yellow-mantled Weaver Ploceus tricolor, it can easily be distinguished by its black belly in all plumages. Furthermore the Golden Weaver $P$. preussi and $P$. tricolor are birds of the canopy and also often of secondary forests. They are never found in the same strata as the Gola Malimbe (Figure 6).

Immature and female plumages indicate a very close relationship between the two species ballmanni and racheliae. The colour distribution of the males, on the other hand, differs considerably between the species. The male of ballmanni is the only member of the genus with cinnamon-coloured feathers (nape spot) and thereby constitutes a link to the genus Ploceus (Field 1979), as we already had with the song (see above). However, according to Hall and Moreau (1970) the ten species of Malimbus are so similar to Ploceus in structure and habits that their separation in another genus is largely a matter of convenience.

\section{Conservation perspectives}

The population of Malimbus ballmanni in the Gola Forest of Sierra Leone and Liberia has already been separated from the population in eastern Liberia and Ivory Coast by a broad band of massive forest destruction between Monrovia and Ganta (Figures 2,3). Based on observations around Zwedru, Sapo National Park and also in some places in Ivory Coast, we estimate the total eastern population to be between than 20,000 and 50,000 birds, but find numbers of the bird in western Liberia much less easy to gauge. However, in view of the rapid northwards retreat of the forest limits in the west of the country in the last three years before the civil war, this population must be considered highly endangered. The same is true at the other end of the species's range, in Ivory Coast, with for example widespread forest clearance in the area of the GuigloTai-Tabou road and to the west of it.

The large population in eastern Liberia also faces fragmentation and decline, since the area has been divided into a number of blocks by the destruction of forest along the roads from Tappita-Zwedru-Sinoe and Zwedru-Harper. These blocks are diminishing in size through the advance of slash-and-burn farming; all the forest around Zwedru itself and adjacent to the Cavalla River is already highly fragmented (Gatter in prep. and Figure 3). Moreover, the whole central and eastern parts of Liberia are being logged by foreign companies, under the protection of troops loyal to rebel Chief Taylor. Worst of all, recent (1992 and 1993) reports from former Liberian foresters now living in Ivory Coast are that heavy logging has extended into several areas of Sapo National Park, and cannot be controlled. There will be no chance of implementing any conservation measures there, or indeed in the other forested areas where the species occurs, until the war ends. 
However, M. ballmanni is found not only in primary forest but also in moderately and heavily logged forests (though not in typical secondary forest), and this gives the species a chance of survival for at least ten years in eastern Liberia. Clearly, conservation agencies must be ready to begin work as soon as opportunities arise for reconstruction in the country.

\section{Acknowledgements}

We are grateful to G. Allport and L. Fishpool for comments made in their capacity as referees. Thanks also go to Prof. H. Mattes and P. Gatter for their help with drawings.

\section{References}

Allport, G. (1991) The status and conservation of threatened birds in the Upper Guinea forest. Bird Conserv. Internatn. 1: 53-74.

Allport, G., Ausden, M., Hayman, P. V., Robinson, P. and Wood P. (1989) The conservation of the birds of Gola forest, Sierra Leone. Cambridge, U.K.: International Council for Bird Preservation (Study Report 38).

Brosset, A. and Erard, C. (1986) Les oiseaux des regions forestières du nord-est du Gabon, 1 . Paris: Société National de Protection de la Nature.

Coe, M. (1986) The biogeographic context. Pp. 13-18 in P. R. Colston and K. CurryLindahl, eds. The birds of Mount Nimba, Liberia. London: British Museum (Natural History).

Collar, N. J. and Stuart, S. N. (1985) Threatened birds of Africa and related islands. Cambridge, U. K., and Gland, Switzerland: International Council for Bird Preservation and International Union for Conservation of Nature and Natural Resources.

Collar, N. J. and Stuart, S. N. (1988) Key forests for threatened birds in Africa. Cambridge, U.K.: International Council for Bird Preservation (Monogr. 3).

Colston, P. R. and Curry-Lindahl, K. (1986) The birds of Mount Nimba, Liberia. London: British Museum (Natural History).

Dutson, G. and Branscombe, J. (1990) Rainforest birds in south-west Ghana. Cambridge, U.K.: International Council for Bird Preservation (Study Report 46).

Field, G. D. (1979) A new species of Malimbus sighted in Sierra Leone and a review of the genus. Malimbus 1: 2-13.

Gartshore, M. E. (1989) An avifaunal survey of Taï National Park, Ivory Coast. Cambridge, U.K.: International Council for Bird Preservation (Study Report 39).

Gatter, P. (1986) Notizen zur Biologie des Herkuleskäfers Dynastes centaurus (Fabricius) in Liberia. Coleoptera: Dynastinae. Ent. Zeitschr. 96: 17-22.

Gatter, W. (1984) For future natural forest and plantation management in Liberia: observations, considerations, results. Monrovia: Forestry Development Authority.

Gatter, W. (1985) Ein neuer Bülbül aus Westafrika (Aves, Pycnonotidae). J. Orn. 126: $155-161$.

Gatter, W. (1987a) Zugverhalten und Überwinterung von paläarktischen Vögeln in Liberia (Westafrika). Verh. Orn. Ges. Bayern 24: 479-508.

Gatter, W. (1987b) Bird migration in West Africa: observations and hypotheses on migration strategies and migration routes. Vogelwarte 34: 80-92.

Gatter, W. (1988a) The birds of Liberia (West Africa). A preliminary list with status and open questions. Verh. Orn. Ges. Bayern 24: 689-723.

Gatter, W. (1988b) The coastal wetlands of Liberia: their importance for wintering waterbirds. Cambridge, U.K.: International Council for Bird Preservation (Study Report 26).

Gatter, W. (in prep.) The birds of Liberia. (British Ornithologists' Union Check-list). 
Gatter, W. and Mattes, H. (1987) Anpassungen von Schafstelze Motacilla flava und afrikanischen Motacilliden an die Waldzerstörung in Liberia (Westafrika). Verh. Orn. Ges. Bayern 24: 467-477.

Grimes, L. G. (1987) The birds of Ghana. London: British Ornithologists' Union (Check-list 9).

Haffer, J. (1992) Parapatric species of birds. Bull. Brit. Orn. Club 12: 250-264.

Hall, B. P. and Moreau, R. E. (1970) An atlas of speciation of African passerine birds. London: British Museum of Natural History.

Hamilton, A. C. (1982) Environmental history of East Africa. London: Academic Press.

Mackworth-Praed, C. W. and Grant C. H. B. (1970) The birds of central and western Africa. London: Longman.

Mattes, H. and Gatter, W. (1989) Jahresperiodik und Biometrie von Andropadus latirostris Strickland (Aves: Pycnonotidae) in Liberia. Stuttgarter Beitr. Naturk. Ser. A., 429: 1-10. Prigogine, A. (1981) A new species of Malimbus from Sierra Leone? Malimbus 3: 55.

White, F. (1979) The Guineo-Congolian region and its relationships to other phytochoria. Bull. Jard. Bot. Nat. Belg. 49(172): 11-55.

Wolters, H. E. (1974) Aus der Vogelsammlung des Museums Koenig. Bonn. zool. Beitr. 25: 283-291.

\section{WULF GATTER}

Buchsstraße 20,73252 Oberlenningen, Germany

RODERICK GARDNER

27 Dover Park Drive, London SW15 5BD, U.K. 